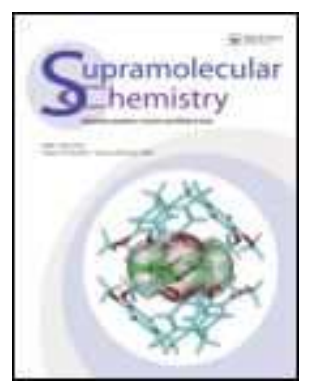

\title{
Association of Quaterpyridine Complex Cations with Polyanionometallates
}

\begin{tabular}{|r|l|}
\hline Journal: & Supramolecular Chemistry \\
\hline Manuscript ID: & GSCH-2008-0075.R2 \\
\hline Manuscript Type: & Special Issue Paper \\
\hline Author: & O4-Oct-2008 \\
\hline Complete List of Authors: & $\begin{array}{l}\text { Ciesielski, Artur; Adam Mickiewicz University } \\
\text { Stefankiewicz, Artur; Adam Mickiewicz University } \\
\text { Wa3êsa, Monika; Adam Mickiewicz University } \\
\text { KUbicki, Maciej; Adam Mickiewicz University } \\
\text { Patroniak, Violetta; Adam Mickiewicz University } \\
\text { Hnatejko, Zbigniew; Adam Mickiewicz University } \\
\text { Harrowfield, Jack; ISIS }\end{array}$ \\
\hline Keywords: & $\begin{array}{l}\text { Quaterpyridine, transition metal complexes, polyanionometallates, } \\
\text { luminescence }\end{array}$ \\
\hline $\begin{array}{l}\text { Note: The following files were submitted by the author for peer review, but cannot be converted } \\
\text { to PDF. You must view these files (e.g. movies) online. }\end{array}$ \\
\hline Figure1.cdx
\end{tabular}

\section{$\diamond$ ScholaroNE" \\ Manuscript Central}




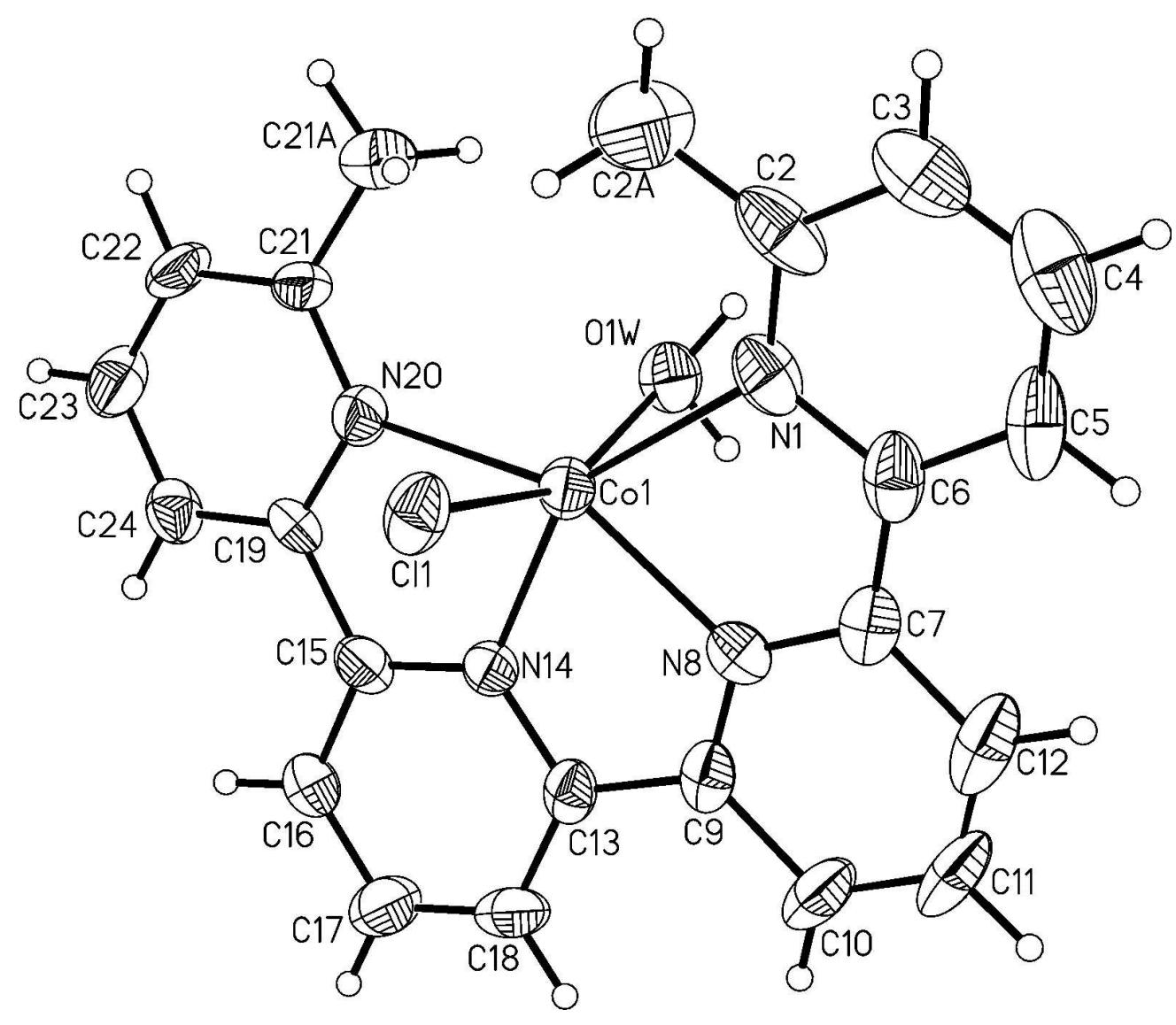

$202 \times 174 m m(600 \times 600$ DPI $)$ 


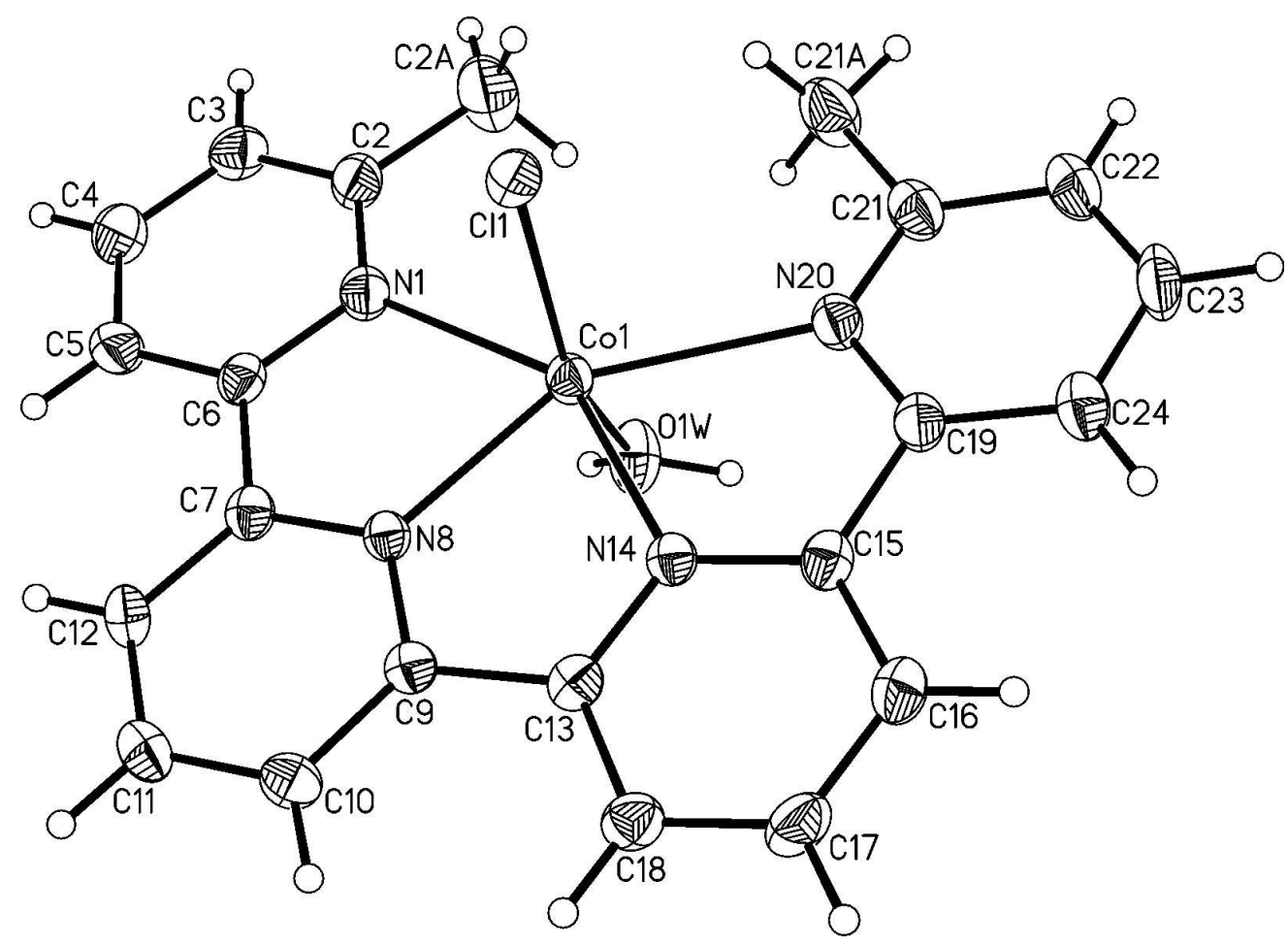

$206 \times 150 \mathrm{~mm}(600 \times 600 \mathrm{DPI})$ 


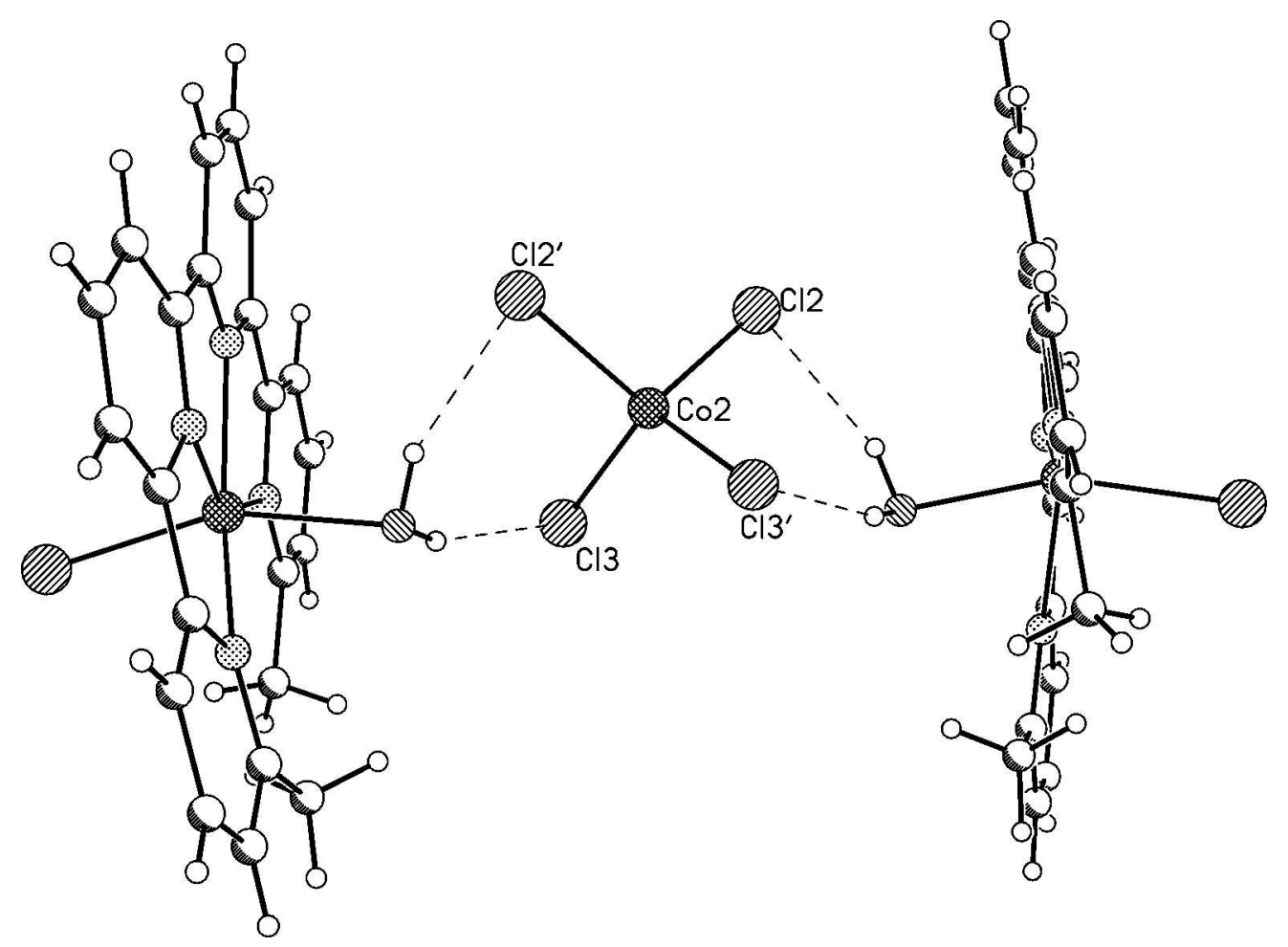

$198 \times 145 \mathrm{~mm}(600 \times 600 \mathrm{DPI})$ 


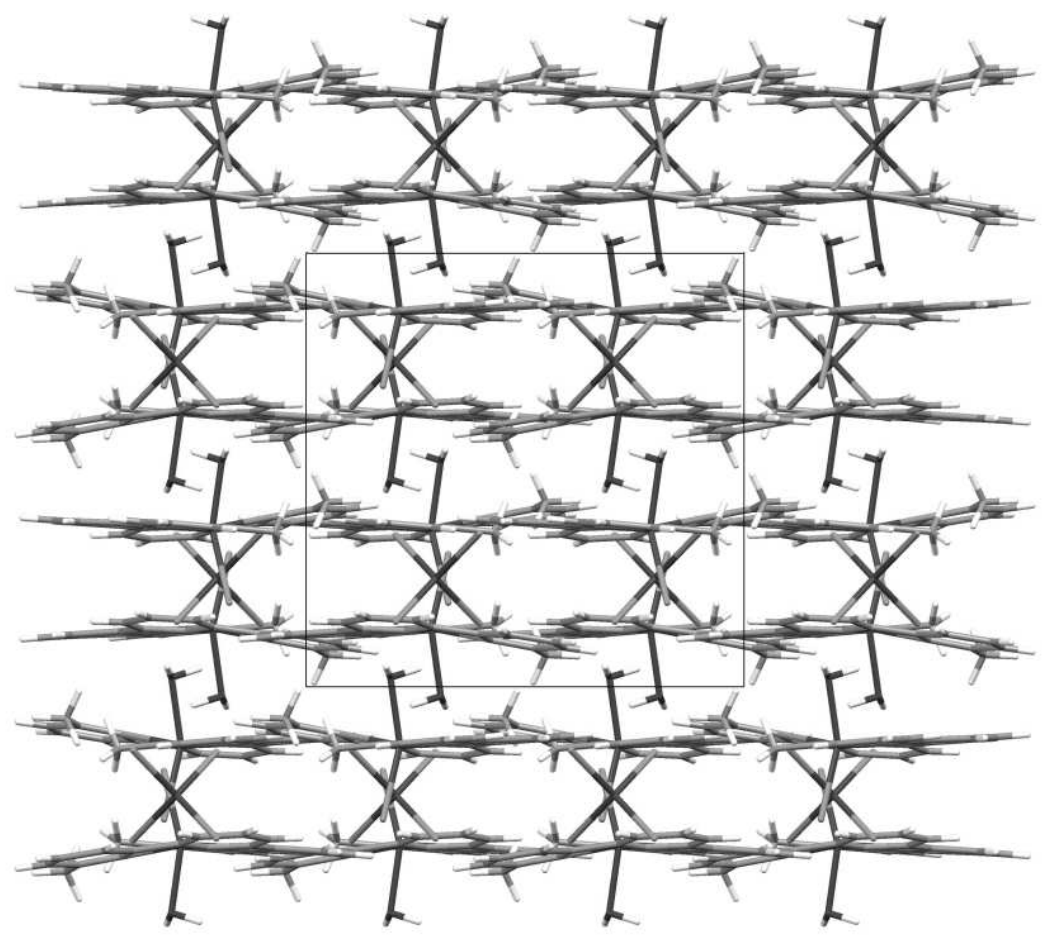

$43 \times 38 \mathrm{~mm}(600 \times 600 \mathrm{DPI})$

39

40

42

43

45

46

47

48

49

51 




$199 \times 153 \mathrm{~mm}(600 \times 600$ DPI $)$ 


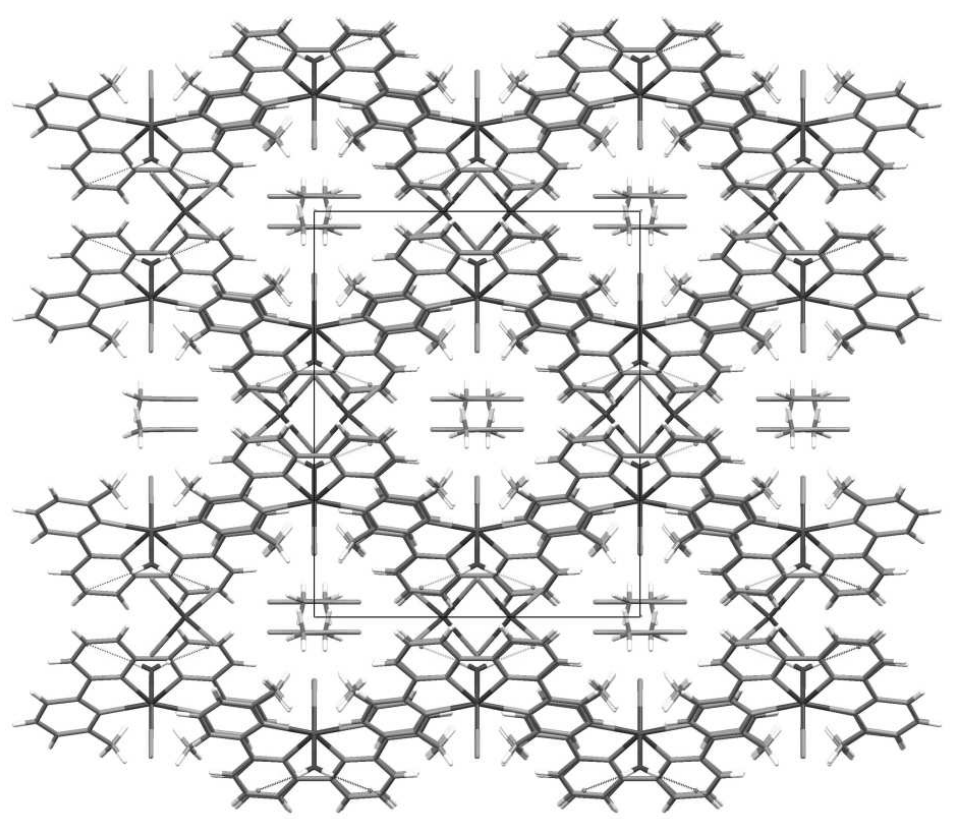

$54 \times 43 \mathrm{~mm}(600 \times 600 \mathrm{DPI})$ 


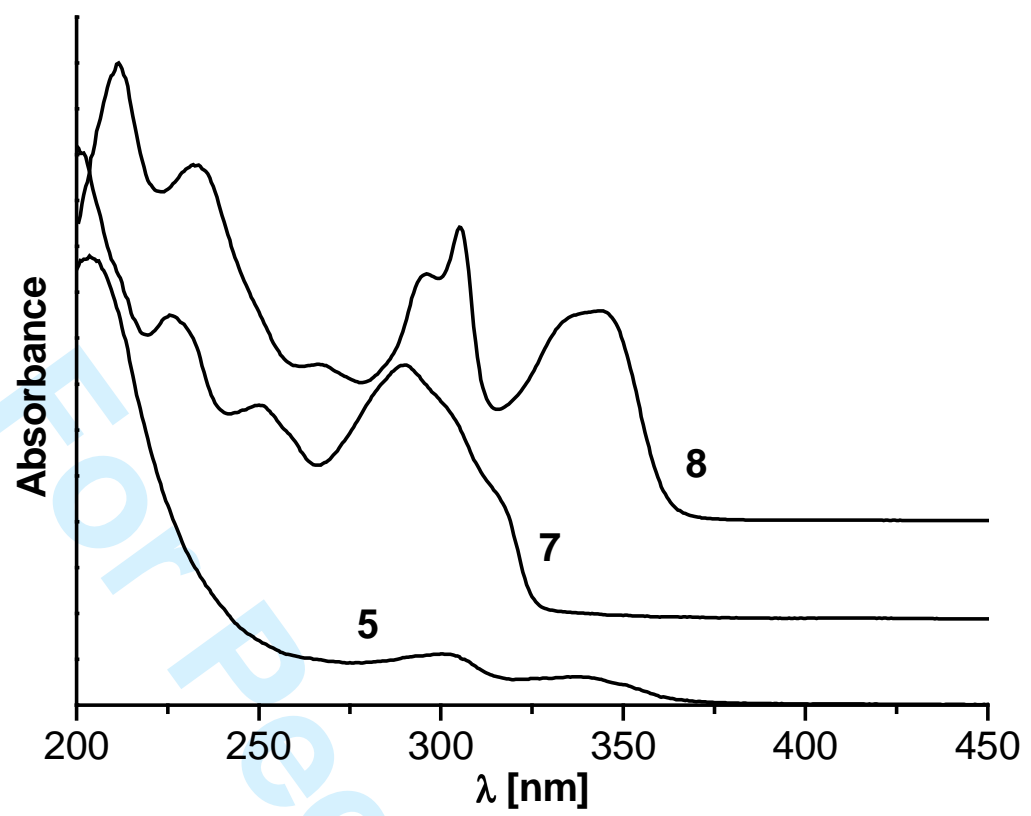




\title{
Association of Quaterpyridine Complex Cations with Polyanionometallates
}

\author{
ARTUR CIESIELSKI, ARTUR R. STEFANKIEWICZ, MONIKA WAŁESA- \\ CHORAB, VIOLETTA PATRONIAK, MACIEJ KUBICKI, ZBIGNIEW HNATEJKO \\ and JACK M. HARROWFIELD
}

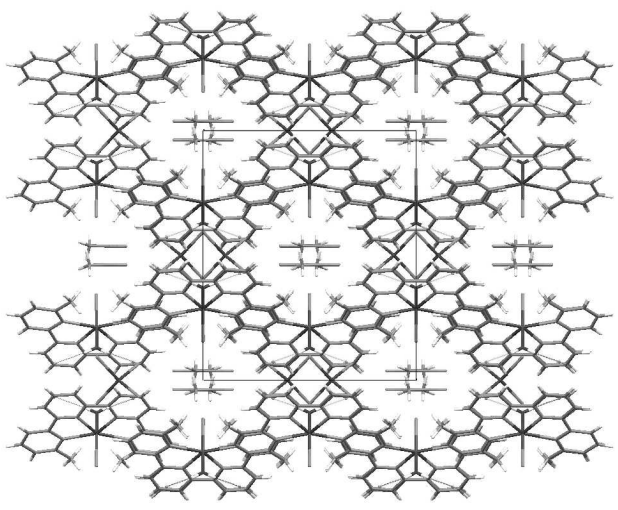




\section{Association of Quaterpyridine Complex Cations with Polyanionometallates}

ARTUR CIESIELSKI ${ }^{\mathrm{a}, \mathrm{b}}$, ARTUR R. STEFANKIEWICZ ${ }^{\mathrm{a}, \mathrm{b}}$, MONIKA WAEESACHORAB $^{\mathrm{a}}$, VIOLETTA PATRONIAK ${ }^{*, \mathrm{~b}}$, MACIEJ KUBICKI ${ }^{\mathrm{a}}$, ZBIGNIEW HNATEJKO ${ }^{\mathrm{a}}$, JACK M. HARROWFIELD ${ }^{\mathrm{b}}$

${ }^{a}$ Faculty of Chemistry, Adam Mickiewicz Univesity, Grunwaldzka 6, 60780 Poznań, Poland bISIS, Université Louis Pasteur, 8, Allée Gaspard Monge, BP 70028, 67083 Strasbourg, France;

Reactions in $\mathrm{CH}_{3} \mathrm{CN}: \mathrm{CH}_{2} \mathrm{Cl}_{2}$ (2:1) under $\mathrm{Ar}$ of the dimethyl-quaterpyridine ligand $\mathrm{C}_{22} \mathrm{H}_{18} \mathrm{~N}_{4}(\mathrm{~L})$ with $\mathrm{Mn}\left(\mathrm{ClO}_{4}\right)_{2}, \mathrm{Fe}\left(\mathrm{BF}_{4}\right)_{2}, \mathrm{CoCl}_{2}, \mathrm{Co}\left(\mathrm{NO}_{3}\right)_{2}, \mathrm{Zn}\left(\mathrm{NO}_{3}\right)_{2}, \mathrm{Cd}\left(\mathrm{CH}_{3} \mathrm{COO}\right)_{2}$ and $\mathrm{HgCl}_{2}$ give complexes of the type $\left[\mathrm{ML}\left(\mathrm{H}_{2} \mathrm{O}\right)_{\mathrm{m}} \mathrm{X}_{\mathrm{n}}\right]_{2}\left[\mathrm{MX}_{\mathrm{p}}\right]$, where $\mathrm{X}$ denotes the initial counterions, with $m=1, n=1, p=4$ or $m=2, n=0, p=6$. The complexes have been characterized by spectroscopic techniques and elemental analysis. The solid state structures of two forms of the $\mathrm{CoCl}_{2}$ complex have been established by $\mathrm{X}$-ray crystallography, enabling an analysis of the interactions occurring in crystals of this type.

Keywords: Quaterpyridine; transition metal complexes; polyanionometallates; luminescence

\section{INTRODUCTION}

The coordination chemistry of polypyridines [1] and of bipyridines [2-4], terpyridines [1,5,6] and quaterpyridines $[7,8]$ in particular, is a field of major interest because of the often remarkable physical and chemical properties of the very diverse metal ion complexes of both the parent ligands and numerous sophisticated derivatives [9]. The range of their applications includes those as molecular machines [10], liquid crystals [11], catalysts for both organic and inorganic reactions [9d,12], and as both therapeutic and imaging agents in medicine [13]. While quaterpyridine chemistry has been relatively limited in development because of synthetic inaccessibility, we have recently described [7] the rather facile synthesis of the dimethylquaterpyridine $\mathrm{L}$ (Figure 1) and have shown that it may act as a helical quadridentate ligand forming both mononuclear (with octahedral $\mathrm{Co}(\mathrm{II})$ and $\mathrm{Zn}(\mathrm{II})$ ) and binuclear, "helicate" (with tetrahedral $\mathrm{Cu}(\mathrm{I})$ and $\mathrm{Ag}(\mathrm{I}))$ complexes.

\footnotetext{
${ }^{*}$ Corresponding author.E-mail: violapat@amu.edu.pl
} 


\section{Insert Figure 1}

\section{FIGURE 1 The ligand $\mathbf{L}$.}

In the present work, we extend these studies of the coordination chemistry of L with transition metal ions in the poor anion-solvating solvent acetonitrile [14]. The consequence of the use of this solvent with the particular metal reactants now chosen is that the solids deposited from the reaction mixtures contain $\mathrm{L}$ bound in a cationic species which is associated with a polyanionometallate counterion. The stoichiometry of the isolated solid depends upon the nature of both the metal cation and the simple anion with which it is initially associated.

\section{EXPERIMENTAL SECTION}

The metal salts were used without further purification as supplied from Aldrich. The ligand $\mathbf{L}$ and the complex $\left[\mathrm{ZnL}\left(\mathrm{H}_{2} \mathrm{O}\right)_{2}\right]\left(\mathrm{CF}_{3} \mathrm{SO}_{3}\right)_{2} 8$ were prepared as described previously [7]. Solvents were freshly distilled under argon from $\mathrm{CaH}_{2}$. NMR spectra were run on a Varian Gemini $300 \mathrm{MHz}$ spectrometer and were calibrated against the residual protonated solvent signals $\left(\mathrm{CD}_{3} \mathrm{CN}: \delta 1.94\right)$. Mass spectra for acetonitrile solutions $\sim 10^{-4} \mathrm{M}$ were determined using a Waters Micromass ZQ spectrometer. Sample solutions were introduced into the mass spectrometer source with a syringe pump at a flow rate of $40 \mu \mathrm{L} \mathrm{min}{ }^{-1}$ with a capillary voltage of $+3 \mathrm{kV}$ and a desolvation temperature of $300^{\circ} \mathrm{C}$. The source temperature was $120{ }^{\circ} \mathrm{C}$. The cone voltage $\left(\mathrm{V}_{\mathrm{c}}\right)$ was set to $30 \mathrm{~V}$ to allow transmission of ions without fragmentation processes. Scanning was performed from $\mathrm{m} / \mathrm{z}=200$ to 1000 for $6 \mathrm{~s}$, and 10 scans were summed to obtain the final spectrum. Microanalyses were obtained using a Perkin Elmer 2400 CHN microanalyzer. All absorption spectra were recorded with a Shimadzu UVPC 2001 spectrophotometer, between 200 and $600 \mathrm{~nm}$, in 10 x $10 \mathrm{~mm}$ quartz cells using solutions acetonitrile $10^{-5} \mathrm{M}$ with respect to the metal ion. Excitation and emission spectra were measured at room temperature on a Perkin-Elmer MPF3 spectrofluorimeter with excitation and emission slits at $10 \mathrm{~nm}$.

Preparation of the complexes - general procedures: All complexes were prepared under similar conditions. A mixture of appropriate metal salt $(27 \mu \mathrm{mol})$ and ligand $\mathbf{L}(9 \mathrm{mg}, 27$ $\mu \mathrm{mol})$ in 2:1 $\mathrm{CH}_{3} \mathrm{CN}-\mathrm{CH}_{2} \mathrm{Cl}_{2}(10 \mathrm{~mL})$ was stirred at room temperature for $48 \mathrm{~h}$ under argon. The volume was reduced under vacuum until crystallization commenced and the mixture was 
then allowed stand to equilibrate. The product was obtained as a powder and was washed on the filter with $\mathrm{CH}_{2} \mathrm{Cl}_{2}$. The yields were: $88-97 \%$.

Mn(II) Complex (1): ESI-MS(+):= 492 (40) $\left[\mathrm{MnL}\left(\mathrm{ClO}_{4}\right)\right]^{+}, 195$ (100) $[\mathrm{MnL}]^{2+}$. ESI-MS(-): $\mathrm{m} / \mathrm{z}(\%)=352(100)\left[\mathrm{Mn}\left(\mathrm{ClO}_{4}\right)_{3}\right]^{-}, 226(40)\left[\mathrm{Mn}\left(\mathrm{ClO}_{4}\right)_{4}\right]^{2-}$. Elemental analysis (\%) caldc for $\left[\mathrm{Mn}\left(\mathrm{C}_{22} \mathrm{H}_{18} \mathrm{~N}_{4}\right)\left(\mathrm{ClO}_{4}\right)\left(\mathrm{H}_{2} \mathrm{O}\right)\right]_{2}\left[\mathrm{Mn}\left(\mathrm{ClO}_{4}\right)_{4}\right]$ (1474.36): C, 35.84; H, 2.73; N, 7.60; found: C $35.81 ; \mathrm{H} 2.80 ; \mathrm{N} 7.61$.

Fe(II) Complex (2): ${ }^{1} \mathrm{H}$ NMR (300 MHz, $\left.\mathrm{CD}_{3} \mathrm{CN}\right): \delta=8.66$ (d, 2H, J=5.7 Hz), 8.49 (t, 2H, $J=6.9 \mathrm{~Hz}), 8.07$ (t, 2H, J=5.7 Hz), 7.70 (d, 2H, J=2.4 Hz), 7.54 (d, 2H, J=6.3 Hz), 7.21 (d, 2H, $J=5.7 \mathrm{~Hz}), 3.09\left(\mathrm{~s}, 6 \mathrm{H}, \mathrm{CH}_{3}\right) . \mathrm{ESI}-\mathrm{MS}(+): \mathrm{m} / \mathrm{z}(\%)=429(100)[\mathrm{Fe} \mathbf{L C l}]^{+}, 198(40)[\mathrm{FeL}]^{2+}$. ESI-MS(-): m/z $(\%)=202(40)\left[\mathrm{Fe}\left(\mathrm{BF}_{4}\right)_{4}\right]^{2-}, 145(15)\left[\mathrm{Fe}\left(\mathrm{BF}_{4}\right)_{6}\right]^{4-}$. Elemental analysis $(\%)$ caldc for $\left[\mathrm{Fe}\left(\mathrm{C}_{22} \mathrm{H}_{18} \mathrm{~N}_{4}\right)\left(\mathrm{H}_{2} \mathrm{O}\right)_{2}\right]_{2}\left[\mathrm{Fe}\left(\mathrm{BF}_{4}\right)_{6}\right]$ (1438.17): C, 36.77; H, 3.09; N, 7.80; found: C $36.74 ; \mathrm{H} 3.07$; N 7.77 .

Co(II) Complex (3): $\quad \operatorname{ESI}-\mathrm{MS}(+): \quad \mathrm{m} / \mathrm{z} \quad(\%)=432 \quad(80) \quad[\mathrm{CoLCl}]^{+}, \quad 237$ (55) $\left[\mathrm{CoL}\left(\mathrm{CH}_{3} \mathrm{CN}\right)\left(\mathrm{H}_{2} \mathrm{O}\right)_{2}\right]^{2+}, 207(5)\left[\mathrm{CoL}\left(\mathrm{H}_{2} \mathrm{O}\right)\right]^{2+}, 199(20)[\mathrm{CoL}]^{2+}$. ESI-MS(-): m/z (\%) = 164 (100) $\quad\left[\mathrm{CoCl}_{3}\right]^{-} ; \quad 101$ (13) $\quad\left[\mathrm{CoCl}_{4}\right]^{2-}$. Elemental analysis (\%) caldc for $\left[\mathrm{Co}\left(\mathrm{C}_{22} \mathrm{H}_{18} \mathrm{~N}_{4}\right) \mathrm{Cl}\left(\mathrm{H}_{2} \mathrm{O}\right)\right]_{2}\left[\mathrm{CoCl}_{4}\right]$ (1102.36): C 47.94; H 3.66; N 10.16; found: $\mathrm{C}, 47.81 ; \mathrm{H}$, $3.65 ; \mathrm{N}, 10.03$.

Co(II) Complex (4): ESI-MS(+): m/z $(\%)=459(25)\left[\mathrm{CoL}\left(\mathrm{NO}_{3}\right)\right]^{+}, 199(30)[\mathrm{CoL}]^{2+}$. ESIMS(-): m/z $(\%)=245(45)\left[\mathrm{Co}\left(\mathrm{NO}_{3}\right)_{3}\right]^{-}, 154(40)\left[\mathrm{Co}\left(\mathrm{NO}_{3}\right)_{4}\right]^{2-}$. Elemental analysis for $\left[\mathrm{Co}\left(\mathrm{C}_{22} \mathrm{H}_{18} \mathrm{~N}_{4}\right)\left(\mathrm{NO}_{3}\right)\left(\mathrm{H}_{2} \mathrm{O}\right)\right]_{2}\left[\mathrm{Co}\left(\mathrm{NO}_{3}\right)_{4}\right]$ (1261.67): C, 41.89; H, 3.20; N, 15.54; found: $\mathrm{C}$ 41.84; H 3.17; N 15.50 .

Zn(II) Complex (5): ${ }^{1} \mathrm{H}$ NMR $\left(300 \mathrm{MHz}, \mathrm{CD}_{3} \mathrm{CN}\right): \delta=8.58(\mathrm{~d}, 2 \mathrm{H}, J=8.7 \mathrm{~Hz}), 8.48(\mathrm{t}, 2 \mathrm{H}$, $J=6.4 \mathrm{~Hz}), 8.18$ (t, 2H, J=5.4 Hz), 7.50 (d, 2H, J=6.6 Hz), 7.44 (d, 2H, J=7.2 Hz), 7.18 (d, 2H, $J=6.0 \mathrm{~Hz}), 2.98\left(\mathrm{~s}, 6 \mathrm{H}, \mathrm{CH}_{3}\right) . \operatorname{ESI}-\mathrm{MS}(+): \mathrm{m} / \mathrm{z}(\%)=263(80)\left[\mathrm{ZnL}\left(\mathrm{CH}_{3} \mathrm{CN}\right)_{3}\right]^{2+}, 210(15)$ $\left[\mathrm{ZnL}\left(\mathrm{H}_{2} \mathrm{O}\right)\right]^{2+}, 203(20)[\mathrm{ZnL}]^{2+}$. ESI-MS(-): m/z $(\%)=250(100)\left[\mathrm{Zn}\left(\mathrm{NO}_{3}\right)_{3}\right]^{-}, 157$ (40) $\left[\mathrm{Zn}\left(\mathrm{NO}_{3}\right)_{4}\right]^{2-}$. Elemental analysis for $\left[\mathrm{Zn}\left(\mathrm{C}_{22} \mathrm{H}_{18} \mathrm{~N}_{4}\right)\left(\mathrm{NO}_{3}\right)\left(\mathrm{H}_{2} \mathrm{O}\right)\right]_{2}\left[\mathrm{Zn}\left(\mathrm{NO}_{3}\right)_{4}\right]$ (1281.04): C, 41.25; H, 3.15; N, 15.31; found: C 41.29; H 3.18; N 15.30. 
Cd(II) Complex (6): ${ }^{1} \mathrm{H}$ NMR (300 MHz, $\left.\mathrm{CD}_{3} \mathrm{CN}\right): \delta=8.49(\mathrm{~d}, 2 \mathrm{H}, J=8.4 \mathrm{~Hz}), 8.41(\mathrm{t}, 2 \mathrm{H}$, $J=5.7 \mathrm{~Hz}), 8.31$ (d, 2H, J=7.8 Hz), 8.16 (d, 2H, J=7.5 Hz), 7.99 (t, 2H, J=7.8 Hz), 7.50 (d, 2H, $J=7.5 \mathrm{~Hz}), 2.22\left(\mathrm{~s}, 6 \mathrm{H}, \mathrm{CH}_{3}\right) . \operatorname{ESI}-\mathrm{MS}(+): \mathrm{m} / \mathrm{z}(\%)=511(100)\left[\mathrm{CdL}\left(\mathrm{CH}_{3} \mathrm{OO}\right)\right]^{+}, 339(30)$ $[\mathbf{L H}]^{+}, 306(10)\left[\mathrm{Cd} \mathbf{L}\left(\mathrm{CH}_{3} \mathrm{CN}\right)_{4}\right]^{2+}, 244(20)\left[\mathrm{Cd} \mathbf{L}\left(\mathrm{CH}_{3} \mathrm{CN}\right)\right]^{2+}, 225(15)[\mathrm{CdL}]^{2+}$. ESI-MS(-): $\mathrm{m} / \mathrm{z}(\%)=289(50)\left[\mathrm{Cd}\left(\mathrm{CH}_{3} \mathrm{COO}\right)_{3}\right]^{-}, 174(40)\left[\mathrm{Cd}\left(\mathrm{CH}_{3} \mathrm{COO}\right)_{4}\right]^{2-}, 136(30)\left[\mathrm{Cd}\left(\mathrm{CH}_{3} \mathrm{COO}\right)_{5}\right]^{3-}$ . Elemental analysis calcd. for $\left[\mathrm{Cd}\left(\mathrm{C}_{22} \mathrm{H}_{18} \mathrm{~N}_{4}\right)\left(\mathrm{CH}_{3} \mathrm{COO}\right)\left(\mathrm{H}_{2} \mathrm{O}\right)\right]_{2}\left[\mathrm{Cd}\left(\mathrm{CH}_{3} \mathrm{COO}\right)_{4}\right]$ (1404.34): C, 47.89; H, 4.16; N, 7.98; found: C, 47.91; H, 4.19; N, 8.01.

Hg(II) Complex (7): ${ }^{1} \mathrm{H}$ NMR (300 MHz, $\left.\mathrm{CD}_{3} \mathrm{CN}, 25^{\circ} \mathrm{C}\right): \delta=8.89(\mathrm{~d}, 2 \mathrm{H}, J=8.3 \mathrm{~Hz}), 8.78(\mathrm{t}$, $2 \mathrm{H}, J=7.4 \mathrm{~Hz}), 8.58(\mathrm{t}, 2 \mathrm{H}, J=6.4 \mathrm{~Hz}), 8.41$ (d, 2H, J=6.1 Hz), $7.94(\mathrm{~d}, 2 \mathrm{H}, J=7.5 \mathrm{~Hz}), 7.38$ (d, $2 \mathrm{H}, J=6.5 \mathrm{~Hz}), 2.48\left(\mathrm{~s}, 6 \mathrm{H}, \mathrm{CH}_{3}\right) . \operatorname{ESI}-\mathrm{MS}(+): \mathrm{m} / \mathrm{z}(\%)=301(100)\left[\mathrm{HgL}\left(\mathrm{CH}_{3} \mathrm{CN}\right)\left(\mathrm{H}_{2} \mathrm{O}\right)\right]^{2+}$, $277(35)\left[\mathrm{HgL}\left(\mathrm{H}_{2} \mathrm{O}\right)\right]^{2+}, 270(25)[\mathrm{HgL}]^{2+}$. ESI-MS(-): m/z (\%) = 307 (60) $\left[\mathrm{HgCl}_{3}\right]^{-}, 170$ (45) $\left[\mathrm{HgCl}_{4}\right]^{2-}, 127$ (40) $\left[\mathrm{HgCl}_{5}\right]^{3-}, 102$ (100) $\left[\mathrm{HgCl}_{6}\right]^{4-}$. Elemental analysis calcd. for $\left[\mathrm{Hg}\left(\mathrm{C}_{22} \mathrm{H}_{18} \mathrm{~N}_{4}\right)\left(\mathrm{H}_{2} \mathrm{O}\right)_{2}\right]_{2}\left[\mathrm{HgCl}_{6}\right]$ (1563.36): C, 33.80; H, 2.84; N, 7.17; found: C, 33.83; H, $2.86 ; \mathrm{N}, 7.20$.

\section{X-Ray Crystallography}

Both forms of the cobalt complex crystallized symultanously from the acetonitile solution as the blue prisms. Diffraction data were collected at room temperature (3A) and 100(1)K (3B) by the $\omega$-scan technique, on a KUMA-KM4CCD diffractometer [15] with graphitemonochromated $\mathrm{MoK}_{\alpha}$ radiation $(\lambda=0.71073 \AA)$. The temperature was controlled by an Oxford Instruments Cryosystems cooling device. The data were corrected for Lorentz-polarization and absorption effects [15]. Accurate unit-cell parameters were determined by a least-squares fit of $2236(\mathbf{3 A})$ and $8354(\mathbf{3 B})$ reflections of highest intensity, chosen from the whole experiment. The structures were solved with SHELXS97 [16] and refined with the full-matrix least-squares procedure on $\mathrm{F}^{2}$ by SHELXL97 [16]. Scattering factors incorporated in SHELXL97 were used. All non-hydrogen atoms were refined anisotropically and hydrogen atoms of water fragment in $\mathbf{3 B}$ were found in difference Fourier map but all other hydrogen atoms were located geometrically and refined as 'riding model' with their $\mathrm{U}_{\text {iso }}$ 's set at 1.2 (1.4 for $\mathrm{CH}_{3}$ groups) of the $\mathrm{U}_{\mathrm{eq}}$ 's of the appropriate carrier atoms. In the structure of $\mathbf{3 B}$ the anionic fragment is disordered over two positions, sharing two common $\mathrm{Cl}$ atoms; the site occupation factors refined at 0.826(3) and 0.174(3). Relevant crystal data are listed in Table 1, together with refinement details. 
Table 1. Crystal data, data collection and structure refinement

\begin{tabular}{|c|c|c|}
\hline Compound & $\mathbf{3 A}$ & 3B \\
\hline Formula & $\begin{array}{c}{\left[\mathrm{Co}\left(\mathrm{C}_{22} \mathrm{H}_{18} \mathrm{~N}_{4}\right) \mathrm{Cl}\left(\mathrm{H}_{2} \mathrm{O}\right)\right]_{2}} \\
{\left[\mathrm{CoCl}_{4}\right]}\end{array}$ & $\begin{array}{c}{\left[\mathrm{Co}\left(\mathrm{C}_{22} \mathrm{H}_{18} \mathrm{~N}_{4}\right) \mathrm{Cl}\left(\mathrm{H}_{2} \mathrm{O}\right)\right]_{2}} \\
{\left[\mathrm{CoCl}_{4}\right] \times 2 \mathrm{CH}_{3} \mathrm{CN}}\end{array}$ \\
\hline Formula weight & 1102.34 & 1184.44 \\
\hline Crystal system & monoclinic & monoclinic \\
\hline Space group & $\mathrm{C} 2 / \mathrm{c}$ & $\mathrm{C} 2 / \mathrm{c}$ \\
\hline $\mathrm{a}(\AA)$ & $25.950(12)$ & $16.4768(5)$ \\
\hline $\mathrm{b}(\AA)$ & $13.283(5)$ & $14.1032(5)$ \\
\hline $\mathrm{c}(\AA)$ & $14.237(7)$ & $22.9752(8)$ \\
\hline$\beta\left(^{0}\right)$ & $112.36(4)$ & $92.547(3)$ \\
\hline $\mathrm{V}\left(\AA^{3}\right)$ & $4538(3)$ & $5333.6(3)$ \\
\hline $\mathrm{Z}$ & 4 & 4 \\
\hline $\mathrm{D}_{\mathrm{x}}\left(\mathrm{g} \mathrm{cm}^{-3}\right)$ & 1.61 & 1.48 \\
\hline $\mathrm{F}(000)$ & 2236 & 2412 \\
\hline$\mu\left(\mathrm{mm}^{-1}\right)$ & 1.49 & 1.27 \\
\hline Crystal size $(\mathrm{mm})$ & $0.05 \times 0.05 \times 0.3$ & $0.15 \times 0.2 \times 0.2$ \\
\hline$\Theta$ range $\left(^{0}\right)$ & $2.9-20.0$ & $2.6-25.0$ \\
\hline \multicolumn{3}{|l|}{ Reflections: } \\
\hline Measured & 6905 & 21200 \\
\hline unique $\left(\mathrm{R}_{\text {int }}\right)$ & $2083(0.077)$ & $4675(0.041)$ \\
\hline with $\mathrm{I}>2 \sigma(\mathrm{I})$ & 1350 & 3395 \\
\hline Number of parameters & 287 & 330 \\
\hline $\mathrm{R}(\mathrm{F})\left[\mathrm{F}^{2}>2 \sigma\left(\mathrm{F}^{2}\right)\right]$ & 0.079 & 0.059 \\
\hline $\mathrm{wR}\left(\mathrm{F}^{2}\right)$ [all refl.] & 0.203 & 0.185 \\
\hline Goodness of fit & 1.05 & 1.14 \\
\hline $\max / \min \Delta \rho\left(\mathrm{e} \AA^{-3}\right)$ & $1.00 /-0.43$ & $2.42 /-0.50$ \\
\hline
\end{tabular}

Crystallographic data (excluding structure factors) for the structural analysis have been deposited with the Cambridge Crystallographic Data Centre, Nos. CCDC-690352 (3A) and CCDC-690353 (3B). Copies of this information may be obtained free of charge from: The Director, CCDC, 12 Union Road, Cambridge, CB2 1EZ, UK. Fax: +44(1223)336-033, email:deposit@ccdc.cam.ac.uk, or www: www.ccdc.cam.ac.uk.

\section{RESULTS AND DISCUSSION}


In contrast to the results of our earlier work where reactions of $\mathrm{Co}(\mathrm{II})$ and $\mathrm{Zn}$ (II) salts with an equimolar quantity of $\mathrm{L}$ in acetonitrile produced crystalline materials containing the $\mathrm{M}(\mathrm{II})$ in a complex cation only, reactions of different salts of Co and $\mathrm{Zn}$, as well as of salts of other M(II) species, in acetonitrile:dichloromethane (2:1) have provided solids in which the present evidence is that the metal ions are present in both cationic and anionic species. Thus, despite the use of preparative mixtures containing the metals and $\mathrm{L}$ in a 1:1 molar ratio, the materials precipitated were found from elemental microanalysis to have these components present in 3:2 ratio (M:L). The blue colour of the $\mathrm{Co}(\mathrm{II})$ complexes in particular was suggestive of the presence of tetrahedral anionometallates $\left(\left[\mathrm{CoCl}_{4}\right]^{2-}\right.$ and $\left.\left[\mathrm{Co}\left(\mathrm{NO}_{3}\right)_{4}\right]^{2-}\right)$ and $\mathrm{X}$-ray structure determinations (see below) of two different solvates of the complex derived from $\mathrm{CoCl}_{2}$ showed the presence of $\left[\mathrm{CoCl}_{4}\right]^{2-}$, associated with two $\left[\mathrm{CoL}\left(\mathrm{OH}_{2}\right) \mathrm{Cl}\right]^{+}$cations, in both. Although attempts to obtain crystals suitable for structure determinations failed with all other complexes, in all cases electrospray mass spectra did provide evidence that anionometallate species could be present in the solids. Whilst it is somewhat surprising that complexes of perchlorate and tetrafluoroborate anions might be obtained under the preparative conditions used, the solvent mixture used should be a particularly poor anion solvator and, from the stoichiometry of the isolated solids, it is clear that even allowing for metal ion bridging by water ligands, at least some degree of metal ion/anion binding must occur in all cases. Thus, with cautionary acknowledgements that "double salts" in general adopt a multitude of forms, that oligomeric rather than mononuclear anionometallates might be present in some of the solids and that well-studied $\mathrm{Hg}$ (II) systems have shown that the relationship between stoichiometry and structure can be very varied, we present the materials isolated as forming two series $\left[\mathrm{ML}\left(\mathrm{H}_{2} \mathrm{O}\right)_{\mathrm{m}} \mathrm{X}_{\mathrm{n}}\right]_{2}\left[\mathrm{MX} \mathrm{p}_{\mathrm{p}}\right]$, where $\mathrm{X}$ denotes the initial counterions, with $\mathrm{m}=1, \mathrm{n}=1, \mathrm{p}=4\left(\mathbf{1}, \mathrm{M}=\mathrm{Mn}, \mathrm{X}=\mathrm{ClO}_{4}^{-} ; \mathbf{3}, \mathbf{4}, \mathrm{M}=\mathrm{Co}, \mathrm{X}=\mathrm{Cl}^{-}, \mathrm{NO}_{3}^{-}: \mathbf{5}, \mathrm{M}=\mathrm{Zn}, \mathrm{X}=\mathrm{NO}_{3}{ }^{-}\right.$ ; 6, $\left.\mathrm{M}=\mathrm{Cd}, \mathrm{X}=\mathrm{CH}_{3} \mathrm{CO}_{2}{ }^{-}\right)$or $\mathrm{m}=2, \mathrm{n}=0, \mathrm{p}=6\left(\mathbf{2}, \mathrm{M}=\mathrm{Fe}, \mathrm{X}=\mathrm{BF}_{4}{ }^{-} ; \mathbf{7}, \mathrm{M}=\mathrm{Hg}, \mathrm{X}=\mathrm{Cl}^{-}\right)$.

\section{Crystallographic Characterization of Complex 3}

In both structures there are different Co complexes: one di-anionic $\mathrm{CoCl}_{4}{ }^{2-}$ and two cations, in which Co central ion is coordinated by four nitrogen atoms of $\mathbf{L}$ and chlorine atom and water molecule. In the complex $\mathbf{3 B}$ there is an additional solvent - acetonitrile molecule that occupies the empty spaces in the crystal structure. It might be noted that the crystal structure of $\mathbf{3 B}$ is less efficiently packed as can be deduced from the differences in the calculated densities (cf. Table 2). 
Table 2. Selected bond distances $(\AA)$ and angles $\left(^{\circ}\right)$ and torsion angles with e.s.d.'s in parentheses.

\begin{tabular}{|l|l|l|}
\hline & $\mathbf{3 A}$ & $\mathbf{3 B}$ \\
\hline Co-Cl(anion) & $2.244(4)$ & $2.276(1)$ \\
& $2.279(4)$ & $2.293(1)$ \\
\hline Co-Cl(cation) & $2.305(4)$ & $2.3503(15)$ \\
\hline Co-O1W & $2.111(8)$ & $2.046(4)$ \\
\hline Co-N & $2.126(10)$ & $2.113(4)$ \\
& $2.129(11)$ & $2.117(4)$ \\
& $2.345(11)$ & $2.392(4)$ \\
& $2.393(10)$ & $2.401(4)$ \\
\hline Cl-Co-Cl (anion) & $114.7(2)$ & $108.34(8)$ \\
& $109.20(14)$ & $108.43(5)$ \\
\hline Cl-Co-O1W & $107.28(15)$ & $114.38(5)$ \\
\hline Cl-Co-N & $155.7(3)$ & $155.8(1)$ \\
& $89.5(3)$ & $102.8(1)$ \\
& $100.3(3)$ & $88.4(1)$ \\
& $94.4(3)$ & $88.9(1)$ \\
& $91.0(3)$ & $102.0(1)$ \\
\hline O1W-Co-N & $99.0(3)$ & $96.3(2)$ \\
& $94.4(3)$ & $96.9(2)$ \\
& $81.7(4)$ & $83.0(1)$ \\
& $81.2(3)$ & $82.6(1)$ \\
\hline
\end{tabular}

Figures 2 and 3 show the perspective views of the cations with the numbering scheme, while Table 3 lists relevant geometrical parameters of the structural elements for both crystals.

Table 3. Hydrogen bond data

\begin{tabular}{|lllllll|}
\hline $\mathbf{D}$ & $\mathbf{H}$ & $\mathbf{A}$ & $\mathbf{D}-\mathbf{H}$ & $\mathbf{H} \cdots \mathbf{A}$ & $\mathbf{D} \cdots \mathbf{A}$ & $\mathbf{D}-\mathbf{H} \cdots \mathbf{A}$ \\
\hline & & $\mathbf{3 A}$ & & & \\
\hline O1W & $\mathrm{H} 1$ & $\mathrm{Cl} 2$ & 0.90 & 2.32 & $3.158(3)$ & 154 \\
\hline O1W & $\mathrm{H} 2$ & $\mathrm{Cl} 3(-\mathrm{x}, \mathrm{y},-\mathrm{z}-1 / 2)$ & 0.90 & 2.34 & $3.192(3)$ & 158 \\
\hline & & & $\mathbf{3 B}$ & & & \\
\hline O1W & $\mathrm{H} 1$ & $\mathrm{Cl}$ & 0.96 & 2.26 & $3.192(1)$ & 164 \\
\hline O1W & $\mathrm{H} 2$ & $\mathrm{Cl} 3(-\mathrm{x}, \mathrm{y}, 3 / 2-\mathrm{z})$ & 0.92 & 1.98 & $2.862(6)$ & 162 \\
\hline
\end{tabular}




\section{Insert Figure 2}

FIGURE 2 Perspective view of the cation $\mathrm{Co}\left(\mathbf{L C l H}_{2} \mathrm{O}\right)^{+}$in $\mathbf{3 A}$ together with the numbering scheme. The displacement ellipsoids are drawn at $25 \%$ probability level.

\section{Insert Figure 3}

FIGURE 3 Perspective view of the cation $\mathrm{Co}\left(\mathbf{L C l H}_{2} \mathrm{O}\right)^{+}$in $\mathbf{3 B}$ together with the numbering scheme. The displacement ellipsoids are drawn at 50\% probability level.

The anions are close to ideal tetrahedrons; in $\mathbf{3 B}$ the anions are disordered over two alternative positions, and the shape of the less-occupied molecule is distorted, but that might be the artifact of disorder itself.

The coordination polyhedron of Co in cationic complexes is a distorted octahedron (or tetragonal bipyramid). Four nitrogen atoms of $\mathbf{L}$ make the basal plane (maximum deviation from the least squares plane through four atoms is $0.074(5) \AA$ in $\mathbf{3 A}$ and $0.005(2) \AA$ in $\mathbf{3 B}$ ), and $\mathrm{Cl}$ and $\mathrm{O}$ atoms are on the opposite sites. The central Co atom is slightly but significantly out of the basal plane (by 0.161(5) $\AA$ in 3A and 0.119(2) $\AA$ in 3B), always the deviation is towards the $\mathrm{Cl}$ atom.

The structural units are made of two cations and a dianion. In $\mathbf{3 A}$ the $\mathrm{O}-\mathrm{H} \cdots \mathrm{Cl}$ hydrogen bonds connect both water hydrogen atoms ( $\mathrm{H} 1$ and $\mathrm{H} 2)$ with different $\mathrm{Cl}$ atoms of the anions (Figure 4); the geometry of these hydrogen bonds is quite typical (Table 3).

\section{Insert Figure 4}

FIGURE 4 The structural unit in $\mathbf{3 A}$. Hydrogen bonds are depicted as dashed lines, two cations are related by the two-fold axis of symmetry that also halves the anion.

These symmetrical units - the dianion occupies the special position, on the twofold axis - are packed into the sheets of approximately parallel cations (the dihedral angle between the planes of the rings in the unit is about $6^{\circ}$ ), separated by dianion - water systems and chlorine atoms from the cations (Figure 5). This structure is densely packed, and this tendency probably causes relatively large folding of the ligand $\mathbf{L}$. The dihedral angle between least squares planes of the terminal rings is $12.7(4)^{\circ}$.

\section{Insert Figure 5}

FIGURE 5 The crystal packing - supramolecular architecture in $\mathbf{3 A}$ as seen along a-direction. 
In $\mathbf{3 B}$ also the hydrogen bonds between water molecules and anions organize the structural unit. In this case however, due to the disorder in the structure the water molecule uses only one hydrogen bond for each alternative positions of the anion (Figure 6).

Insert Figure 6

FIGURE 6 The structural unit in 3B. Hydrogen bonds are depicted as dashed lines, two cations are related by the two-fold axis of symmetry that also halves the anion. The open lines show the anion of lesser occupancy.

This disorder (over pseudo-mirror plane of symmetry) leads to the less dense packing, which causes more planar conformation of the ligand: dihedral angle between the terminal rings is as small as $1.2(3)^{\circ}$. What's more, this packing leads to the huge empty spaces in the crystal structures which are occupied by the solvent - acetonitrile molecules (Figure 7).

\section{Insert Figure 7}

FIGURE 7 The crystal packing - supramolecular architecture in 3B as seen along a-direction. The free spaces, occupied by the solvent molecules, are clearly seen.

\section{Electronic Absorption Spectra and Luminescence Properties}

Absorption spectra of solutions of the ligand $\mathbf{L}$ and complexes 1-7 in acetonitrile are characterized by high-energy absorptions at about $210 \mathrm{~nm}$ and low-energy bands at ca. 300 and $340 \mathrm{~nm}$, respectively. The electronic absorption spectra in the UV region show the typical $\pi-\pi^{*}$ ligand-based transitions.

The complexes $1, \mathbf{3}, \mathbf{4}, \mathbf{5}, \mathbf{6}$ and $\mathbf{2 ,} \mathbf{7}$ exhibits a quite similar absorption profiles respectively and different for the previously investigated of mononuclear $\mathrm{Zn}$ (II) complex $\left[\mathrm{ZnL}\left(\mathrm{H}_{2} \mathrm{O}\right)_{2}\right]\left(\mathrm{CF}_{3} \mathrm{SO}_{3}\right)_{2} 8$ [7]. In the UV-region, where the ligand centered transitions are dominant, the differences in the recorded spectra for the three type of complexes (mononuclear, two types of complexes containing three metal ions) are observed (Figure 8, Table 4). The absorption spectra of $\mathbf{5 , 7}$ and $\mathbf{8}$ are depicted in Figure 8.

\section{Insert Figure 8}

FIGURE 8 The absorption spectra of $\mathbf{5 , 7}$, and $\mathbf{8}$ in acetonitrile $\left(5 \times 10^{-5} \mathbf{M}\right)$ solution at $298 \mathrm{~K}$. The luminescence properties of free ligand $\mathbf{L}$ and its metal complexes 1-7 were also investigated in $\mathrm{CH}_{3} \mathrm{CN}$ at room temperature and quantum yield of luminescence was determined. Ligand $\mathbf{L}$ and complexes exhibit one broad emission band. The emission band maxima of all complexes are red-shifted compared to free ligand $\mathbf{L}$. The quantum yields of the luminescence of $\mathbf{1}, \mathbf{4 , 5}$ and $\mathbf{6}$ complexes are much lower than the of free ligand under the 
same conditions. The $\mathrm{Mn}(\mathrm{II})$ and $\mathrm{Co}(\mathrm{II})$ ions strong quenching the luminescence of $\mathbf{L}(\phi=$ 0.0043 and 0.0067), while $\mathrm{Zn}$ (II) and Cd(II) weakly ( $\phi=0.0168$ and 0.0177). Complex 3 does not display luminescence in this solution. The quantum yields of complexes $\mathbf{2}$ and $\mathbf{7}$ are higher than the others, but they are lower than the quantum yield of free ligand. The emission of the zinc triflate mononuclear complex (8) is much more intense then ligand $\mathbf{L}$ [7]. The determined quantum yield of this complex is equal 0.2151 and it is higher than ligand $\mathbf{L}$.

Table 4. Absorption and luminescence data

\begin{tabular}{|c|l|c|c|}
\hline Compound & \multicolumn{1}{|c|}{ Absorption, $\lambda / \mathrm{nm}\left(\varepsilon \times 10^{3} / \mathrm{M}^{-1} \mathrm{~cm}^{-1}\right)$} & Emission, $\lambda / \mathrm{nm}$ & $\phi_{\mathrm{em}}{ }^{*}$ \\
\hline $\mathbf{L}$ & $209(31), 252(17), 292.5(25)$ & 359 & 0.0752 \\
\hline $\mathbf{1}$ & $\begin{array}{l}210(16.9), 234.5(9.7), 267.5(4.0), 307.5 \\
(10.6), 338.5(5.4), 350(5.5)\end{array}$ & 362 & 0.0043 \\
\hline $\mathbf{2}$ & $207(29.7), 288.5(9.4)$ & 363 & 0.0361 \\
\hline $\mathbf{3}$ & $211(23.7), 253(10.0), 302(5.9), 338.5(3.1)$ & - & - \\
\hline $\mathbf{4}$ & $210(14.3), 301(2.2), 339.5(1.2)$ & 366 & 0.0067 \\
\hline $\mathbf{5}$ & $206(13.9), 301.5(1.3) 340(1.0)$ & 365 & 0.0168 \\
\hline $\mathbf{6}$ & $206(19.0), 291.5(4.5), 301(4.3), 338(1.1)$ & 365 & 0.0177 \\
\hline $\mathbf{7}$ & $207(35.7), 231(29.7), 290(16.1)$ & 366 & 0.0453 \\
\hline
\end{tabular}

quininie sulfate $\left(\phi=0.577\right.$ in $\left.0.1 \mathrm{M} \mathrm{H}_{2} \mathrm{SO}_{4}\right)$ was used as a standard for all systems; experimental error ca.20\% [17,18].

The differences in the luminescence properties of studied complexes, especially zinc complexes, suggest that the emission in those systems are sensitive in respect of coordination changes.

\section{CONCLUSIONS}

In conclusion, the investigated complexes may be of use in several fields of coordination chemistry. Geometrical parameters for the $\left[\mathrm{CoCl}_{4}\right]^{2-}$ anion in complex $\mathbf{3}$, whose formation apparently aids the stabilization of the $\left[\mathrm{CoLCl}\left(\mathrm{H}_{2} \mathrm{O}\right)\right]^{+}$cations in crystal lattice, are similar to those reported previuosly for this units [19-29]. These factors of these complexes in solution make these compounds good candidates as luminescence supramolecular nanodevices and laser materials [30-32]. Transition metal complexes of multidentate ligands have been widely 


\section{References}

[1] Early, broad reviews include (a) Constable, E. C. Adv. Inorg. Chem. Radiochem. 1986, 30, 69; (b) Constable, E. C. Progr. Inorg. Chem. 1994, 42, 67 and references therein.

[2] Fraser, C. L.; Smith, A. P. in McCleverty, J. A., Meyer, T. J. Comprehensive Coordination Chemistry II, Elsevier, New York, 2003, Vol. 1, Ch. 1.

[3] Kaes, C.; Katz, A.; Hosseini, M. W. Chem. Rev. 2000, 100, 3553.

[4] Constable, E. C. Adv. Inorg. Chem. 1989, 34, 1.

[5] (a) Constable, E. C. Chem. Soc. Rev. 2007, 36, 246; (b) Constable, E. C. Coord. Chem. Rev. 2008, 252, 842.

[6] Schubert, U. S.; Hofmeier, H.; Newkome, G. R. Modern Terpyridine Chemistry, WileyVCH, Weinheim, 2006.

[7] Stefankiewicz, A. R.; Wałęsa, M.; Jankowski, P.; Ciesielski, A.; Patroniak, V.; Kubicki, M.; Hnatejko, Z.; Harrowfield, J. M.; Lehn, J-M. Eur. J. Inorg. Chem. 2008, 2910 and references therein.

[8] Studies of closely related quadridentate heterocycles include: (a) Wang, J.; Onions, S.; Pilkington, M.; Stoeckli-Evans, H.; Halfpenny, J. C.; Wallis, J. D. Chem. Commun. 2007, 3628; (b) Jeffery, J. C.; Riis-Johannessen, T.; Anderson, C. J.; Adams, C. J.; Robinson, A.; Argent, S.; Ward, M. D.; Rice, C. R. Inorg. Chem. 2007, 46, 2417; (c) Argent, S. P.; Adams, H.; Riis-Johannessen, T.; Jeffery, J. C.; Harding, L. P.; Clegg, W.; Harrington, R. W.; Ward, M. D. Dalton Trans. 2006, 4996; (d) Riis-Johannessen, T.; Jeffery, J. C.; Robson, A. P. H.; Rice, C. R.; Harding, L. P. Inorg. Chim. Acta 2005, $358,2781$.

[9] See, for example: (a) Campagna, S.; Puntoriero, F.; Nastasi, F.; Bergamini, G.; Balzani, V. Top. Curr. Chem. 2007, 280, 117; (b) Lehn, J-M. Supramolecular Chemistry Concepts and Perspectives, VCH Weinheim, 1995, Ch. 2; (c) Vögtle, F. 
Supramolecular Chemistry, John Wiley and Sons, Chichester, 1991, Ch. 2; (d) De Armond, M. K.; Myrick, M. L. Acc. Chem. Res. 1989, 22, 364.

[10] (a) Kay, E. R.; Leigh, D. A.; Zerbetto, F. Angew. Chem. Int. Ed. 2007, 46, 72; (b) Khuong, T-A. V.; Nuñez, J. E.; Godinez, C. E.; Garcia-Garibay, M. A. Acc. Chem. Res. 2006, 39, 413; (c) Sauvage, J-P. Chem. Commun. 2005, 1507 and references therein.

[11] Tschierske, C. Angew. Chem. Int. Ed. 2000, 39, 2454.

[12] (a) Merlau, M. L.; Mejia, M. P.; Nguyen S. T.; Hupp J. T. Angew. Chem. Int. Ed., 2001, 40, 4239; (b) Ohmori, O.; Fujita M. Chem. Commun. 2004, 1586; (c) Yeung, C.-T.; Yeung, H.-L.; Tsang, C.-S.; Wong, W.-Y.; Kwong, H.-L. Chem. Commun. 2007, 5203.

[13] (a) Hotze, A. C. G.; Kariuki, B. M.; Hannon M. J. Angew. Chem. Int. Ed. 2006, 45, 4839; (b) Vandevyver, C. D. B.; Chauvin, A.-S.; Comby S.; Bünzli J.-C. G. Chem. Commun. 2007, 1716.

[14] Parker, A. J. Chem. Rev. 1969, 69, 1.

[15] Oxford Diffraction. CrysAlis CCD (Version 1.171.32.5) and CrysAlis RED (Version 1.171.32.5). Oxford Diffraction Ltd. 2007.

[16] Sheldrick, G. M. Acta Cryst. 2008 A64, 112.

[17] Demas, J. N.; Crosby, G. A. J. Phys. Chem. 1971, 75, 991.

[18] Lakowicz J. R. Principles of Fluorescence Spectroscopy, 1999, Kluwer Academic/Plenum Publishers, New York, p.53.

[19] Paolucci, G.; Marangoni, G.; Bandoli, G.; Clemente, D. A. J. Chem. Soc. Dalton Trans., 1980, 459.

[20] Moret, E.; Nicoló, F.; Plancherel, D.; Froidevaux P.; Bünzli J.-C. G. Hel. Chim. Acta 1991, 74, 65 .

[21] Radecka-Paryzek, W.; Patroniak, V. Polyhedron 1994, 13, 2125.

[22] van Berkel, P. M.; Driessen, W. L.; Hämäläinen, R.; Reedijk, J.; Turpeinen, U. Inorg. Chem. 1994, 33, 5920.

[23] Nockermann P.; Meyer G. Z. Anorg. Allg. Chem. 2003, 629, 123.

[24] Draper, N. D.; Batchelor, R. J.; Sih, B. C.; Ye, Z.-G.; Leznoff, D. B. Chem. Mater. 2003, 15,1612 .

[25] Eisler, D. J.; Puddephatt, R. J. Inorg. Chem. 2003, 42, 8192.

[26] Song, J.-L.; Mao, J.-G.; Zeng, H.-Y.; Dong, Z.-C. Eur. J. Inorg. Chem. 2004, 538.

[27] Jin, Y.; Yoon, H.; Seo, J.; Lee, J.-E.; Moon, S.-T.; Kim, J.; Han, S. W.; Park, K.-M.; Lindoy L. F.; Lee S. S. Dalton Trans. 2005, 788. 
[28] Sharma, R. P.; Sharma, R.; Bala, R.; Salas, J. M.; Quiros, M. J. Mol. Struct. 2006, 794, 341.

[29] Raj, M. M.; Dharmaraja, A.; Kavitha, S. J.; Panchanatheswaran, K.; Lynch, D. E. Inorg. Chim. Acta 2007, 360, 1799.

[30] Alves, W.A.; de Almeida Filho, S.A.; de Almeida Santos, R.H.; Da Costa Ferreira, A.M. Inorg. Chem. Commun. 2003, 6, 294.

[31] Hamacek, J.; Blanc, S.; Elhabiri, M.; Leize, E.; Van Dorsselaer, A.; Piguet, C.; Albrecht-Gary A.-M. J. Am. Chem. Soc. 2003, 125, 1541.

[32] Müllen, K.; Scherf, U. Organic Light Emitting Devices, Wiley-VCH Verlag, Karlsruhe, 2006.

[33] Leszczyszyn, O. I.; Evans, C. D.; Keiper, S. E.; Warren, G. Z. L.; Blindauer, C. A. Inorg. Chim. Acta 2007, 360, 3.

[34] Jacobsen, F. E.; Lewis, J. A.; Heroux, K. J.; Cohen, S. M. Inorg. Chim. Acta 2007, 360, 264.

[35] Brinksma, J.; Rispens, M.; Hage. R.; Feringa, B. L. Inorg. Chim. Acta 2002, 337, 75.

[36] Hage, R.; Lienke, A. Angew. Chem. Int. Ed. 2006, 45, 206.

[37] Sibbons, K. F.; Shastri, K.; Watkinson, M. Dalton Trans. 2006, 645. 